\title{
Pfannenstiel İnsizyon Bölgesinde Nekrotizan Fasiit, Olgu Sunumu
}

\author{
Necrotizing Fasciitis at Pfannenstiel Incision Region, Case Report
}

\author{
Fedi Ercan 1, Osman Balcı ${ }^{1}$, Bayram Can ${ }^{1}$ \\ 1. Necmettin Erbakan Üniversitesi Meram Tıp Fakültesi Kadın Hastalıkları ve Doğum AD, Perinatoloji Ünitesi, Konya
}

\section{ÖZET}

Giriş: Nekrotizan fasiit (NF), cilt-ciltaltı dokusu ile birlikte fasya nekrozunu da içine alan ağır seyirli subkutan yumuşak doku enfeksiyonudur. Genellikle cerrahi girişim ya da künt travmalar sonrası görülmektedir, ancak intramusküler injeksiyon gibi minor girişim bölgelerinde dahi görülebilmektedir. Doğru tanı koyulmast ve gerekli cerrahi debridman ile rekonstrüktif cerrahi işlemlerin acilen yapılması çok önemlidir. Ancak, bazen erken tanı ve tedaviye rağmen mortalite ve morbiditesi yüksektir. Diyabetes mellitus, karaciğer ve böbrek yetmezliği, çeşitli malignensiler, kronik alkol kullanımı, periferik vasküler hastallklar ve ileri yaş gibi immün sistemi zayıflatan haller bu klinik tablo için zemin hazırlayan durumlardır. Genel olarak mortalite oranı \%20-50 kadardır.

Olgu: Burada Pfannenstiel insizyon ile yapılan jinekolojik kanser cerrahisi sonrasi gelişen bir NF olgusu sunulmaktadır.

Sonuç: NF için tedavinin temelini erken tanl, geniş spektrumlu antibiyotik tedavisi, geride nekrotik doku kalmayacak şekilde sağlam dokulara kadar ve gerektiğinde tekrarlanan debridman oluşturur.

Anahtar Kelimeler: nekrotizan fasiit, histerektomi, pfannenstiel insizyon, batın duvart

\section{ABSTRACT}

Introduction: Necrotizing fasciitis is severe soft tissue that contain with skin-subcutaneous tissue and fascial necrosis, too. Necrotizing fasciitis usuallay occurs post operation and after blunt trauma, even in minör intramusculer injection areas. To correct diagnosis and to make surgical debridement with reconstructive intervention should be very important. In spite of early diagnosis and treatment is high mortality and morbidity. Such as immun system weakening conditions diabetes mellitus, liver and kidney failure, various malignancy, chronic alcohol use, peripheral vasculer diseases, conditions provoke Necrotizing fasciitis mortality of Necrotizing fasciitis ratio is $\% 20-\% 50$.

Case: Necrotizing fasciitis event is presented that occur after cancer gynecological surgery with phannenstiel cut in this article.

Conclusion: Basic of treatment is early diagnosis and wide spectrum antibiotic treatment, to make debridement recurrent until intact tissue catch up necrosis tissue.

Keywords: necrotizing fasciitis, hysterectomy, pfannenstiel incision, abdominal wall
İletişim:

Sorumlu Yazar: Fedi Ercan

Adres: Necmettin Erbakan Üniversitesi Meram Tıp Fakültesi Kadın Hast. ve Doğum AD, Perinatoloji Ünitesi, Konya E-Posta: fediercan@gmail.com

Makale Geliş: 18.03.2015

Makale Kabul: 13.08.2015

DOI: http://dx.doi.org/10.16948/zktb.50161 


\section{GİRİŞ}

Nekrotizan fasiit (NF), cilt-cilt altı dokusu ile birlikte fasya nekrozunu da içine alan ağır seyirli subkutan yumuşak doku enfeksiyonudur. NF vücutta en s1k ekstremitelerde ve özellikle de alt ekstremitelerde görülmekle birlikte herhangi bir lokalizasyonu tutabilir. Genellikle cerrahi girişim ya da künt travmalar sonrası görülmektedir, ancak intramusküler enjeksiyon gibi minör girişim bölgelerinde dahi görülebilmektedir (1). Diabetes mellitus, karaciğer ve böbrek yetmezliği, çeşitli malignensiler, kronik alkol kullanımı, periferik vasküler hastalıklar ve ileri yaş gibi immün sistemi zayıflatan haller bu klinik tablo için zemin hazırlayan durumlardır (2). Doğru tanı konulması ve cerrahi debridman ile rekonstrüktif cerrahi işlemlerin agresif olarak yapılması çok önemlidir. Ancak, bazen erken tanı ve tedaviye rağmen mortalite ve morbidite yüksektir. Genel olarak mortalite oranı \%20-50 kadarken (3), ülkemizde yapılan çalıșmalarda mortalite oranı \%14-33 arasında değişkenlik göstermektedir (4). Yeni Zelanda'da 1990-2006 y1lları arasını içine alan bir insidans çalışmasında sıklığ 1100.000 'de $0,18-1,68$ olarak bulunmuştur ve batın ön duvarına yapılan insizyonlar ve histerektomi sonrası nekrotizan fasiit görülme sıklığı ile ilgili olarak bildirilmiş net bir veri olmamakla birlikte çok daha nadir olduğu sanılmaktadır (5). Ancak abdominal insizyonlar sonrası batın ön duvarında gelișen NF olguları nadiren de olsa bildirilmiștir (6). Literatür tarandığında direkt olarak Pfannenstiel insizyon ile ilişkilendirilmiş NF olgusuna rastlanmamaktadır.

Burada Pfannenstiel insizyon ile yapilan jinekolojik kanser cerrahisi sonrası gelişen bir NF olgusu sunulmaktadır.

\section{OLGU}

Vajinal kanama nedeniyle kadın hastalıkları ve doğum polikliniğine başvuran 75 yaşında G4 P4 olan hastaya yapılan endometrial biopside grade 2 endometrioid adenokarsinom gelmesi üzerine ameliyat kararı verildi. Ameliyattan 30 dakika önce antibiyotik profilaksisi olarak Sefazol 1 gram intravenöz uyguland. Ameliyatta pfannenstiel insizyon ile batın içi sitoloji örnekleme, total abdominal histerektomi, bilateral salpingo-ooforektomi, pelvik paraaortik lenf nodu diseksiyonu (İnferior mezenterik arter seviyesine kadar), omentum örneklemesi uyguland1. Ameliyat süresi 105 dakika olan hastanın ameliyatı sirasında herhangi bir komplikasyon gelişmedi. Ameliyat sonrası 5. günde yara yerinde ağrı, kızarıklık ve 1sı artışı yanında akıntı olan ve acil servise başvuran hastaya yara yeri enfeksiyonu teşhisi ile antibiyotik başlan- mış ve acil servis tarafından poliklinik kontrolü önerilmiştir. Hasta ertesi gün, ağrı şikayetinde artma ve yara yerinde kötü kokulu akıntının yoğunlaşması üzerine polikliniğimize başvurmuș ve ilk değerlendirmede ateş $38,7^{\circ} \mathrm{C}$, kan basınc1 100/60 mmHg, nabiz 106 atım/dakika olarak izlenmiştir. Muayenede vücut kitle indeksi 22 $\mathrm{kg} / \mathrm{m}^{2}$ ve pfannenstiel insizyon bölgesinde pürülan kötü kokulu akıntı mevcuttu (Resim 1).

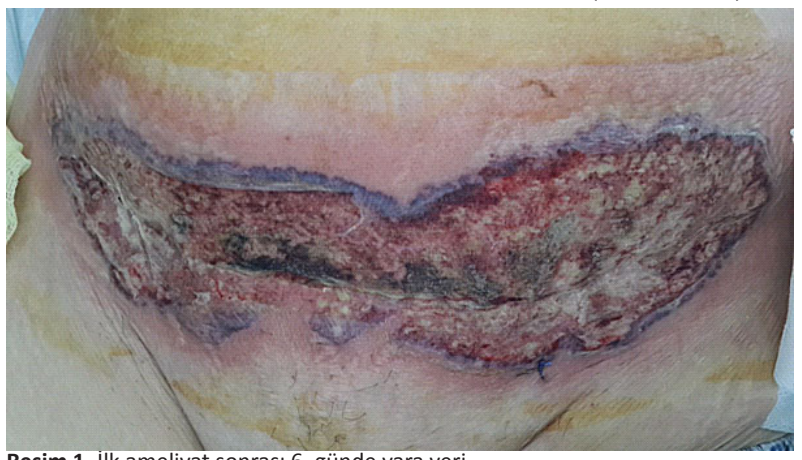

Spekulum muayenesinde vajinal güdük kapalı ve doğal görünümde idi. Tam kan sayımında; hemoglobin 13,0 g/dl, beyaz küre 18,200/ mm3 (\%91 nötrofil) ve trombosit $249,000 / \mathrm{mm} 3$ olarak tespit edildi. Sedimantasyon $45 \mathrm{~mm} / \mathrm{saat}$ ve C-Reaktif Protein $>160 \mathrm{mg} / \mathrm{L}$ olarak görüldü. Kan biyokimyasında tokluk kan şekeri 106 $\mathrm{mg} / \mathrm{dl}$, üre, kreatinin, SGOT ve SGPT değerleri normal sinırlarda olan ancak elektrolitlerden sodyum $129 \mathrm{mmol} / \mathrm{L}$, potasyum 3,0 $\mathrm{mmol} / \mathrm{L}$ ve albumin $2,6 \mathrm{~g} / \mathrm{dl}$ olarak gelen hastaya cilt alt1 yüzeyel doku ultrasonu yapıldı. Yüzeyel doku ultrasonografisi, insizyon bölgesi üstünde subkutan sivı kolleksiyonu ve amfizem bulguları içermekteydi. Kan kültürü ve yara yeri kültürü alındı. Takiben NF ön tanısı ile kliniği yatırılarak Teikoplanin $400 \mathrm{mg} /$ gün ve Piperasilin-Sulbak$\operatorname{tam} 4,5$ gr x 3/gün başlandi. Yara yeri gram boyamasında gram pozitif koklar izlenen hastanın yara yeri kültürü ve kan kültüründe üreme olmad. Yatıșından 2 gün sonra elektrolit imbalansı düzeltildikten sonra anestezi tarafindan ameliyat olabilir kararı verilmesini takiben (antibiyotik tedavisinin 2. gününde) plastik cerrahi kliniğince yara yeri debritmanı yapıldı (Resim 2).

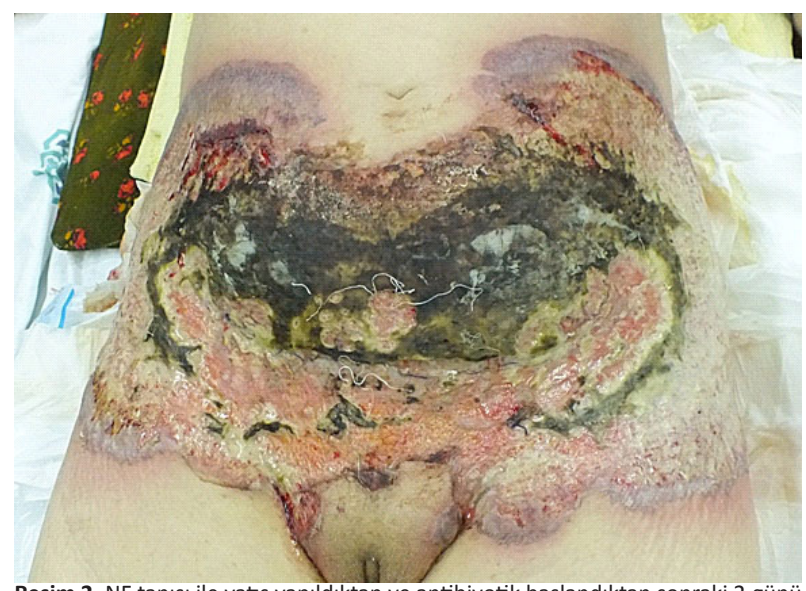

Resim 2. NF tanısı ile yatış ya pild 
Antibiyotik tedavisi debritman sonrasi 14 gün daha devam eden hasta yatışının 22. gününde taburcu edilmiş ve ayaktan poliklinik takibine alınmıştır (Resim 3).

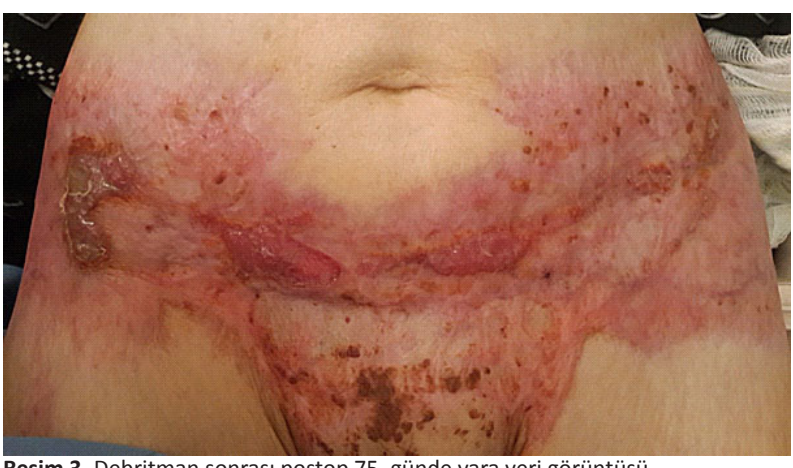

Ameliyat sonrası patolojisi endometrioid tipte histolojik ve nükleer grade 2 adenokarsinom olarak gelen hastanın nihai tanısı endometrium kanseri, evresi ise Evre IB olarak neticelenmiş ve medikal onkoloji takibine geçmiştir.

\section{TARTIŞMA}

NF, vücudun bütün anatomik bölgelerinde görülebilen, cilt altı damar yapısında tromboza ve buna sekonder olarak ciltte nekroza neden olan, mortalite ve morbiditesi oldukça yüksek bir bakteriyel enfeksiyondur (3). NF vücutta en sik ekstremitelerde ve özellikle de alt ekstremitelerde görülmekle birlikte herhangi bir lokalizasyonu tutabilir. Genellikle cerrahi girişim ya da künt travmalar sonrası görülmektedir. Genital sistemi tutan NF'ye Fournier gangreni denir ve kadınlarda labial bölgeden, erkeklerde skrotum bölgesinden başlar ve perine, gluteus ve abdomen ön duvarına hızlı bir şekilde yayılır (7). Erişkinlerde ekstremite tutulumu en sik lokalizasyondur (1). Anlatılan olguda enfeksiyon sahası karın cildi cerrahi insizyon bölgesi olup, malignensi, senilite ve cerrahi travma NF'ye zemin hazırlayan risk faktörleridir (2). NF olgularının \% 70'ten fazlasında diabetes mellitus görülmektedir (8), ancak bu olguda mevcut değildir.

Hastalığın erken döneminde ani başlayan ağrı, şişlik, ciltte eritem görülebilir. Erken dönem bulguları bu hastada da olduğu gibi sıklıkla selüliti taklit eder ve bu nedenle tanı çoğu vakada gecikir. NF için en belirleyici klinik semptom, lezyonun fiziksel görünümüyle tezat oluşturacak kadar yoğun ağrı ve hassasiyettir ve bu durum lezyonun tipik görünümünden saatler önce ortaya çıkabilir (9).

NF'den şüphelenildiğinde yatak başında, lokal anestezi altında parmak testi ve insizyonel biyopsi yapılması önerilmektedir. Derin fasyaya kadar uzanan $2 \mathrm{~cm}$ 'lik kesi yapıldığında ka- namanın olmaması ve bulanık sivı drene olması NF için tipiktir. Parmak derin fasyanın hemen üzerinden ilerlettiğinde, cilt altı dokusu çok az bir dirençle fasyadan ayriliyorsa parmak testi pozitif demektir. Bu NF için anlamlı bir muayene bulgusudur (9).

NF'de tek bir mikroorganizma etken olabileceği gibi polimikrobik de olabilir. Etken çoğunlukla grup A streptokokların virülan formudur. Bazı vakalarda aerop ve anaerop bakterilerin sinerjik etkileri letal enfeksiyona neden olur (10). Yapılan çalışmalarda üreme sıklığına göre bakteriler, aerop streptokoklar, bacteroides türleri, stafilokoklar ve enterokoklar olarak s1ralanır. Yüzde 30 vakada ise yara yeri kültüründe herhangi bir etken üretilememektedir (11). $\mathrm{Bu}$ hastada kan ve yara yeri kültüründe üreme olmamış, yara yeri gram boyamasında ise yoğun gram pozitif koklar izlenmiştir.

Tedavinin temelini erken tanı, geniş spektrumlu antibiyotik tedavisi, geride nekrotik doku kalmayacak şekilde sağlam dokulara kadar ve gerektiğinde tekrarlanan debridman, enfekte bölgenin oksijenizasyonu ile birlikte yeterli oral alımın ve analjezinin sağlanması oluşturur (12). Etken patojen izole edildikten sonra daha önceden başlanmış olan geniş spektrumlu antibiyotik, kültür ve antibiyogram sonucuna göre, gerektiğinde değiştirilmelidir.

$\mathrm{Bu}$ hastalığın cerrahi tedavisinde oluşan defektin genișliğine bakılmaksızın agresif cerrahi debridman yapılmalıdır. Aksi halde ilk debridman yetersiz kaldığında, nekroz hızla ilerleyerek sepsise sebep olabilir. $\mathrm{Bu}$ durum daha da ilerleyerek septik şok ile sonuçlanabilir (3). Yetersiz debridman mortaliteyi artırır ve yaşayan hastalarda tekrarlayan debridmanlara neden olur. $\mathrm{Bu}$ hastaların yara zemini granüle olduğunda ve kültüründe mikroorganizma izole edilmediğinde rekonstrüktif girişimler yapılmalıdır. Hastaların çoğunda defektlerin kısmi kalınlıkta deri grefti ile örtülmesi yeterlidir (9).

$\mathrm{Bu}$ vakada başlangıçta selülit düşünüldügü için acil serviste sefazolin tedavisi başlanmıştı. Ancak NF tanısının ağırlık kazanması ile antibiyotik rejimi Teikoplanin $400 \mathrm{mg} /$ gün ve Piperasilin-Sulbaktam 4,5 gr x 3/gün ile değiştirilmiştir. Yapılan geniş debridman sonrası hastanın yarası takip edilmiş, sekizinci ve 14. günde alınan kontrol kültürlerinde üreme olmamış ve tedavi 21 güne tamamlanmıştır. Hastanın ek debridmana ihtiyacı olmamıştır. Hastaya daha sonra Plastik Cerrahi Kliniğinde deri grefti yapılmıştır. Hasta yaklaşık üç aylık rehabilitasyon tedavisinden sonra günlük yaşantısını dönecek kadar düzelebilmiştir. 
NF tedavisinde son y1llarda hiperbarik oksijen tedavisi önerilmekle birlikte bu uygulamanın etkinliğinin kanıtlanabilmesi için daha fazla çalışmaya gereksinim vardır. Tüm bu gelişmelere rağmen NF, mortalitesi hâlâ çok yüksek (\%33-92) bir enfeksiyondur (11).

Sonuç olarak, NF en sik ekstremitelerde görülebilen, ancak nadiren batın ön duvarı insizyon bölgesinde de rastlanabilen, morbidite ve mortalitesi yüksek ender bir klinik durumdur. Subkutan damarlarda tromboz oluşumu sonucu tutulan bölge cildi üzerinde nekroz olur. Ancak nekroz olması kural değildir. En sık zemin hazırlayıcı risk faktörleri diyabetes mellitus ve obezite olmakla beraber, burada anlatılan hasta diabetik olmamasına ve vücut kitle indeksi normal sınırlarda $(22 \mathrm{~kg} / \mathrm{m} 2)$ olmasına rağmen NF gelişmiştir.

Olguda NF için en belirgin risk faktörleri olarak senilite ve geçirilmiş kanser cerrahisi göze çarpmaktadır. Erken tanı, geniş spekturumlu antibiyotik kullanımı ve agresif cerrahi debridman hayat kurtarıcıdır.

\section{KAYNAKLAR}

1. Wong CH, Chang HC, Pasupathy S, et al. Necrotizing fasciitis: clinical presentation, microbiology, and determinants of mortality. J Bone Joint Surg Am 2003; 85-A:1454.

2. Holland MJ. Application of the Laboratory Risk Indicator in Necrotising Fasciitis (LRINEC) score to patients in a tropical tertiary referral centre. Anaesth Intensive Care 2009; 37:588.

3. Huang $K F$, Hung $M H$, Lin YS, et al. Independent predictors of mortality for necrotizing fasciitis: a retrospective analysis in a single institution. J Trauma 2011; 71:467.

4. Yildirim $Y$, Inal $M$, Tinar S. Necrotizing fasciitis after abdominal hysterectomy: a report on five cases. Arch Gynecol Obstet. 2005;273(2):126-8.

5. Das DK, Baker MG, Venugopal K. Increasing incidence of necrotizing fasciitis in New Zealand: a nationwide study over the period 1990 to 2006. J Infect 2011; 63:429.

6. Cederna JP, Davies BW, Farkas SA, Sonta JA, Sworniowski T. Necrotizing fasciitis of the total abdominal wall after sterilization by partial salpingectomy. Case report and review of literature. Am J Obstet Gynecol. 1990 Jul;163(1 Pt 1):138-9.

7. Eke N. Fournier's gangrene: a review of 1726 cases. Br J Surg 2000; 87:718.

8. Hasham S, Matteucci P, Stanley PR, Hart NB. Necrotising fasciitis. BMJ 2005; 330:830.

9. Jallali N. Necrotizing fasciitis: its aetiology, diagnosis and management. J Wound Care 2003; 12: 297-300.

10. Kaul R, McGeer A, Low DE, et al. Population-based surveillance for group A streptococcal necrotizing fasciitis: Clinical features, prognostic indicators, and microbiologic analysis of seventy-seven cases. Ontario Group A Streptococcal Study. Am J Med 1997; 103:18.

11. Elliot DC, Kufera JA, Myers RA. Necrotizing soft tissue infections. Risk factors for mortality and strategies for management. Ann Surg. 1996; 224: 672-83.

12. Stevens DL, Bisno AL, Chambers HF, et al. Practice guidelines for the diagnosis and management of skin and soft tissue infections: 2014 update by the infectious diseases society of America. Clin Infect Dis 2014; 59:147. 